J. Dairy Sci. 92:4919-4928

doi:10.3168/jds.2009-2104

(c) American Dairy Science Association, 2009.

\title{
Characterization of progesterone profiles in fall-calving Norwegian Red cows
}

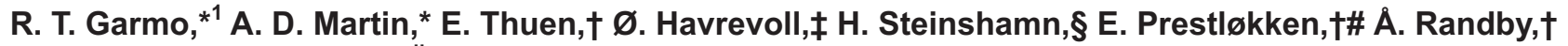 \\ M. Eknæs, † A. Waldmann, $\|$ and O. Reksen* \\ *Norwegian School of Veterinary Science, Department of Production Animal Clinical Sciences, PO Box 8146 Dep., NO-0033 Oslo, Norway \\ †Norwegian University of Life Science, Department of Animal and Aquacultural Sciences, NO-1432 Ås, Norway \\ $\ddagger$ Nortura Rudshøgda, PO Box 70, NO-2360 Rudshøgda, Norway \\ $\S$ Norwegian Institute for Agricultural and Environmental Research, Organic Food and Farming Division, NO-6630 Tingvoll, Norway \\ \#Felleskjøpets Fôrutvikling, NO-7005 Trondheim, Norway \\ ||Estonian University of Life Sciences, Institute of Veterinary Medicine and Animal Sciences, 62 Kreutzwaldi Street, 51014 Tartu, Estonia
}

\begin{abstract}
Progesterone profiles in Norwegian Red cows were categorized, and associations between the occurrence of irregularities in the profiles and the commencement of luteal activity were investigated. The cows were managed in 3 feeding trials from 1994 to 2001 and from 2005 to 2008 at the Norwegian University of Life Sciences. The cows were followed from calving, and the milk samples collected represented 502 lactations from 302 cows. Milk samples for progesterone analysis were taken 3 times weekly from 1994 throughout 1998 and from 2005 to 2008 and 2 times weekly from 1999 to 2001. Commencement of luteal activity was defined as the first day of 2 consecutive measurements of progesterone concentration $\geq 3 \mathrm{ng} / \mathrm{mL}$ not earlier than $10 \mathrm{~d}$ after calving. Delayed ovulation type I was defined as consistently low progesterone concentration, $<3 \mathrm{ng} / \mathrm{mL}$ for $\geq 50 \mathrm{~d}$ postpartum. Delayed ovulation type II was defined as prolonged interluteal interval with milk progesterone measurements $<3 \mathrm{ng} / \mathrm{mL}$ for $\geq 12$ d between 2 luteal phases. Persistent corpus luteum (PCL) type I was defined as delayed luteolysis with milk progesterone $\geq 3 \mathrm{ng} / \mathrm{mL}$ for $\geq 19 \mathrm{~d}$ during the first estrous cycle postpartum. Persistent corpus luteum type II was defined as delayed luteolysis with milk progesterone $\geq 3 \mathrm{ng} / \mathrm{mL}$ for $\geq 19$ d during subsequent estrous cycles before first artificial insemination. Delayed ovulation type I was present in $14.7 \%$, delayed ovulation type II in $2.8 \%$, PCL type I in $6.7 \%$, and PCL type II in $3.3 \%$ of the profiles. Commencement of luteal activity was related to milk yield, parity, PCL type I, and the summated occurrence of PCL type I and II. The least squares means for the interval to commencement of luteal activity were $24.2 \mathrm{~d}$ when PCL type I and II were present and $29.5 \mathrm{~d}$ when PCL type I and II were absent. The
\end{abstract}

Received February 4, 2009.

Accepted July 21, 2009.

${ }^{1}$ Corresponding author: Randi.T.Garmo@veths.no likelihood of pregnancy to first service was not affected in cows with a history of PCL when artificial insemination was carried out at progesterone concentrations $<3$ $\mathrm{ng} / \mathrm{mL}$ (i.e., during estrus); however, cows that had experienced PCL were more likely to be inseminated during a luteal phase. The occurrence of delayed ovulation and PCL in Norwegian Red cows was less than that reported in most other dairy populations.

Key words: progesterone profile, fertility, pregnancy, dairy cow

\section{INTRODUCTION}

The fertility of dairy cows has declined while milk yield has increased in recent decades (Lucy, 2001). The inclusion of fertility indices in dairy cattle breeding has been prioritized to avoid a further decline of fertility due to the unfavorable genetic correlations between milk yield and reproductive performance (Veerkamp et al., 2001; Royal et al., 2002; Pryce et al., 2004). In contrast to the majority of countries, female fertility has been included in the total merit index in the Norwegian Red since 1972 (Andersen-Ranberg et al., 2005; Steine et al., 2008). The relative emphasis on fertility has been 8 to $15 \%$ throughout this period. The populationaverage pregnancy and calving percentage to first AI is estimated to be 61 and $54 \%$, respectively, in this breed (Garmo et al., 2008).

Previous investigations of postpartum progesterone profiles in high-yielding Holstein cows reported the incidence of delayed first ovulation to be between 5.5 and $25.3 \%$, cessation of ovarian activity between 3.3 and $12.9 \%$, and persistent corpus luteum (PCL) between 7.3 and 35.2\% (Opsomer et al., 2000; Royal et al., 2000; Shrestha et al., 2004; Petersson et al., 2006; Samarütel et al., 2008).

A previous study reported that cows with early commencement of luteal activity (C-LA) after calving have an increased probability for early AI, shorter interval to conception, and greater conception rate (Darwash et al., 1997a). However, it has also been reported that 
early C-LA is a risk factor for irregular luteal cyclicity in the form of PCL (Opsomer et al., 2000; Royal et al., 2002; Petersson et al., 2007) and that PCL is associated with a decrease in pregnancy to first AI (Royal et al., 2000; Shrestha et al., 2004). It has also been reported that delayed first ovulation and cessation of cyclical activity increase the calving interval (Petersson et al., 2006) and decrease the pregnancy to first AI (Royal et al., 2000).

Measurement of traditional fertility traits such as nonreturn rate and days to first AI (Garmo et al., 2008), as well as effect of selection for milk yield and fertility on the postpartum interval to C-LA, has been investigated previously in Norwegian Red cows (Garmo et al., 2009). Thus there has been no classification of progesterone patterns postpartum in the breed, and the relationship between the progesterone patterns, C-LA, and subsequent reproductive performance has not yet been investigated.

The objectives for the study were 1) to quantify the occurrence of typical and atypical progesterone profiles in Norwegian Red cows, 2) to assess the relationship between time to C-LA and the occurrence of PCL, and $3)$ to investigate cow- and management-specific factors related to the occurrence of PCL.

\section{MATERIALS AND METHODS}

The milk progesterone data set for the current study was derived from Norwegian Red cows managed in 3 feeding trials designed to assess the effects of different levels of concentrate and different quality of roughage on milk yield, energy balance, and reproduction at the Norwegian University of Life Sciences from 1994 to 2001 and from 2005 to 2008. Complete milk samples were obtained from 502 lactation periods. The distribution of lactations by parity was 180, 170, and 152 for first, second, and >second parity, respectively. The average 305-d milk yields for all lactations in the herd from 1998 to 2008 were $6,275,7,144$, and $7,733 \mathrm{~kg}$ for first, second, and >second lactation, respectively. The average milk fat and milk protein in the bulk milk for 2007 were 4.08 and $3.32 \%$, respectively. The herd consisted of 134 dairy cows in 2007.

\section{Management}

The cows were milked twice daily and housed in either the freestall or the tiestall barn. There were 495 lactations with housing data: 344 lactations in the freestall barn and 151 in the tiestall barn. The breeding season started in November each year such that the voluntary waiting period varied between cows. The cows were on pasture from late May to early September each year.
Table 1. Frequency of reproductive and obstetrical conditions, mastitis, and other diseases before and after commencement of luteal activity $(\mathrm{C}-\mathrm{LA} ; \mathrm{n}=502)$

\begin{tabular}{lcc}
\hline Item & $\begin{array}{c}\text { Before } \\
\text { C-LA }\end{array}$ & $\begin{array}{c}\text { After } \\
\text { C-LA }\end{array}$ \\
\hline Reproductive and obstetrical conditions $^{1}$ & 25 & 27 \\
Clinical mastitis $^{\text {Other diseases }}{ }^{2}$ & 53 & 63 \\
tris $^{2}$ & 18 & 27 \\
\hline
\end{tabular}

${ }^{1}$ Dystocia, retained placenta, metritis, vaginitis, cystic ovaries, abortion.

${ }^{2}$ Laminitis, ketosis, indigestions, milk fever.

Only cows that calved during the fall indoor season were included in the study. Skilled teaching veterinarians from the Ambulatory Practice at the Norwegian School of Veterinary Science performed all AI in the herd during the entire study period. Pregnancy was verified by rectal palpation by veterinarians approximately 6 wk after AI. Cows that did not subsequently deliver a calf $(\mathrm{n}=36)$ were regarded as pregnant to first AI if milk progesterone was $<3 \mathrm{ng} / \mathrm{mL}$ at AI with a subsequent increase in progesterone content $\geq 3 \mathrm{ng} /$ $\mathrm{mL}$ for at least $24 \mathrm{~d}$ after AI. The cows were not exposed to a synchronization program and did not receive any hormone treatment before C-LA. The frequencies of diagnosed reproductive disorders, clinical mastitis, and other diseases before C-LA are presented in Table 1 . Estrus detection was performed daily by visual observation in the morning, afternoon, and late evening. In addition, estrus observations were occasionally carried out during other routine work in the barn. All observations were recorded on a designated 21-d calendar.

\section{Feeding Protocol}

The cows were assigned to different concentrate rations such that the groups were similar in terms of weight, age, and body condition at calving (Edmonson et al., 1989). There were 484 lactations with complete records on concentrate allocation. The distribution of concentrate allocation by parity during peak lactation is presented in Table 2. Cows were given ad libitum access to roughage. The distribution of the feedstuff in the herd in 2007 was $34 \%$ concentrate, $40 \%$ roughage, and $26 \%$ pasture.

\section{Milk Yield and Milk Progesterone}

The average weekly milk yield for the fourth week postpartum was calculated for 430 lactation periods. For an additional 54 lactations with missing records on weekly milk yield, records for monthly milk yield were obtained from the Norwegian Dairy Herd Record System. The milk yield record closest to d 30 of lactation 
Table 2. Distribution of concentrate allocation $(1 \mathrm{~kg}=6.9 \mathrm{MJ})$ in peak lactation by parity from 1994 to $2008(\mathrm{n}=484)$

\begin{tabular}{lccc}
\hline $\begin{array}{l}\text { Concentrate } \\
(\mathrm{kg} / \mathrm{d})\end{array}$ & First parity & Second parity & $>$ Second parity \\
\hline$\leq 6$ & 51 & 58 & 39 \\
$7-9$ & 96 & 26 & 72 \\
$\geq 10$ & 24 & 79 & 39 \\
\hline
\end{tabular}

was used. Together, these 484 observations expressed the milk yield during the fourth week of lactation.

Milk progesterone concentrations were measured in a representative sample of whole milk collected during milking every Monday, Wednesday, and Friday from 1994 throughout $1998(\mathrm{n}=232)$ and from 2005 to 2008 $(\mathrm{n}=143)$ and every Monday and Friday from 1999 to $2001(\mathrm{n}=127)$ by an enzyme immunoassay (Waldmann, 1993) modified by using the second antibody coating technique. The specificity of the antibody has been described previously (Waldmann, 1999). The interassay coefficients of variation for milk progesterone concentrations of 1.48 and $19.66 \mathrm{ng} / \mathrm{mL}$ were 9.21 and $5.32 \%$, respectively. The intraassay coefficient of variation was less than $10 \%$.

\section{Definitions of DOV, C-LA, PCL, Luteal Phase, and Interovulatory Interval}

Delayed ovulation (DOV) type I was defined as consistently low progesterone concentration $(<3 \mathrm{ng} / \mathrm{mL})$ for $\geq 50 \mathrm{~d}$ postpartum. Delayed ovulation type II was defined as prolonged interluteal interval with milk progesterone measurements $<3 \mathrm{ng} / \mathrm{mL}$ for $\geq 12$ d between 2 luteal phases (Royal et al., 2000). There were 502 lactations with data for DOV type I or type II.

The interval from calving to C-LA was defined as the first day of the 2 consecutive measurements of milk progesterone concentration $\geq 3 \mathrm{ng} / \mathrm{mL}$ (Royal et al., 2000) more than $10 \mathrm{~d}$ after calving. Of the 502 lactations, adequate data were available to identify C-LA in 497 lactations. The remaining 5 cows were removed from the herd before C-LA, and these cows had progesterone measurements until 56, 67, 100, 124, and 130 DIM.

Persistent corpus luteum type I, PCL type II, the length of the first luteal phase, and the first interovulatory interval postpartum were measured according to the definitions by Royal et al. (2000). Persistent corpus luteum type I was defined as delayed luteolysis during the first estrous cycle postpartum with milk progesterone $\geq 3 \mathrm{ng} / \mathrm{mL}$ for $\geq 19 \mathrm{~d}$, whereas PCL type II was defined as delayed luteolysis with milk progesterone $\geq 3 \mathrm{ng} / \mathrm{mL}$ for $\geq 19 \mathrm{~d}$ during subsequent estrous cycles before AI. The length of the first luteal phase was measured as the time from the first sample of milk proges- terone $\geq 3 \mathrm{ng} / \mathrm{mL}$ to the last consecutive progesterone sample $\geq 3 \mathrm{ng} / \mathrm{mL}$ (Royal et al., 2000). Among the 497 lactations that were available for the determination of C-LA, individual progesterone samples were missing for 8 lactation periods, and in 9 lactation periods, AI was performed at first estrus. Therefore, the length of the first luteal phase and PCL could be determined for 480 lactations. The same limitation also applies to the assessment of interovulatory intervals. In addition, one cow was culled after the first luteal phase but before the start of a new cycle, such that there were 479 lactations available for the calculation of interovulatory intervals. The length of the interovulatory intervals was considered to be a measurement of the total estrous cycle length and was defined as the interval between the milk progesterone rise $(\geq 3 \mathrm{ng} / \mathrm{mL})$ in one estrous cycle to the rise of milk progesterone $(\geq 3 \mathrm{ng} / \mathrm{mL})$ in the next cycle (Royal et al., 2000). The lengths of the luteal phases and interovulatory intervals were calculated with and without profile abnormalities (DOV and PCL) included (Table 3).

\section{Pregnancy to First Al Related to a Previous Episode of PCL}

Of the 502 lactations included in the study, 476 were presented for AI after calving. Cows in which AI was performed in the luteal phase $(\mathrm{n}=56)$ and one cow (n $=1$ ) experiencing PCL after first AI were omitted. In addition, all profiles with abnormalities were excluded from the baseline control group, such that the occurrence of PCL type I or the summated occurrence of PCL type I and II was compared with only normal progesterone profiles $(\mathrm{n}=316)$.

\section{Al During the Luteal Phase Related to a Previous Episode of PCL}

The definition of first AI during a luteal phase was based on the progesterone measurements taken 2 or 3 times weekly. The exact determination of whether a cow was presented for first AI during the luteal phase was not possible in 26 cows because data on the progesterone measurement within $\pm 2 \mathrm{~d}$ to first AI were missing. These cows were omitted from the analysis. The progesterone measurement closest to AI was at the day for insemination for $37 \%$ of the cows, $\pm 1 \mathrm{~d}$ for $54 \%$, and $\pm 2 \mathrm{~d}$ for $9 \%$ of the cows. In addition, the profiles were evaluated to confirm that these cows actually were inseminated during the luteal phase. One cow that experienced PCL after first AI was also omitted. All profiles with abnormalities were excluded from the baseline control group in the analysis, such that the occurrence of PCL type I, PCL type II, or the summated 
Table 3. Number of lactations and means and $95 \%$ confidence intervals (CI) for the lengths of luteal phases and interovulatory intervals during the first 4 cycles postpartum in Norwegian Red cows presented with profile abnormalities $\left(\mathrm{PCL}^{1}\right.$ and $\left.\mathrm{DOV}^{2}\right)$ included and excluded

\begin{tabular}{lcccccccc}
\hline & \multicolumn{3}{c}{ Luteal phase } & & \multicolumn{3}{c}{ Interovulatory interval } \\
\cline { 2 - 4 } \cline { 7 - 8 } Cycle no. & $\mathrm{n}$ & Mean & $95 \% \mathrm{CI}$ & & $\mathrm{n}$ & Mean & $95 \%$ CI \\
\hline PCL and DOV included & & & & & & & \\
1 & $480^{3}$ & $10.5^{\mathrm{a}}$ & $9.7-11.3$ & & $479^{3}$ & $19.3^{\mathrm{a}}$ & $18.4-20.2$ \\
2 & 376 & $12.5^{\mathrm{b}}$ & $12.0-12.9$ & & 359 & $20.6^{\mathrm{b}}$ & $20.3-21.0$ \\
3 & 261 & $12.4^{\mathrm{b}}$ & $12.0-12.9$ & & 250 & $20.9^{\mathrm{b}}$ & $20.4-21.3$ \\
4 & 153 & $12.5^{\mathrm{b}}$ & $11.9-13.2$ & & 144 & $20.7^{\mathrm{b}}$ & $20.1-21.3$ \\
PCL and DOV excluded & & & & & & & \\
1 & $372^{3}$ & $9.0^{\mathrm{a}}$ & $8.5-9.4$ & & $371^{3}$ & $17.4^{\mathrm{a}}$ & $16.9-18.0$ \\
2 & 300 & $12.3^{\mathrm{b}}$ & $11.9-12.6$ & & 294 & $20.7^{\mathrm{b}}$ & $20.3-21.1$ \\
3 & 210 & $11.9^{\mathrm{b}}$ & $11.5-12.4$ & & 207 & $20.8^{\mathrm{b}}$ & $20.3-21.2$ \\
4 & 124 & $12.2^{\mathrm{b}}$ & $11.6^{\mathrm{b}}-12.7$ & & 121 & $20.7^{\mathrm{b}}$ & $20.1-21.4$ \\
\hline
\end{tabular}

${ }^{a, b}$ Different superscripts under luteal phase indicate significant differences between the lengths of the luteal phases based on the 95\% CI. Different superscripts under interovulatory interval indicate significant differences between the interovulatory intervals based on the $95 \%$ CI.

${ }^{1} \mathrm{PCL}=$ persistent corpus luteum; PCL type $\mathrm{I}=$ delayed luteolysis with milk progesterone concentration $\geq 3$ $\mathrm{ng} / \mathrm{mL}$ for $\geq 19 \mathrm{~d}$ during the first estrous cycle postpartum; PCL type II = delayed luteolysis during estrous cycles after the first cycle postpartum.

${ }^{2} \mathrm{DOV}=$ delayed ovulation; DOV type $\mathrm{I}=$ prolonged anovulatory period with milk progesterone concentration $<3 \mathrm{ng} / \mathrm{mL}$ for $\geq 50 \mathrm{~d}$ postpartum; DOV type II = prolonged interluteal interval with milk progesterone $<3 \mathrm{ng} /$ $\mathrm{mL}$ for $\geq 12 \mathrm{~d}$ between 2 luteal phases.

${ }^{3}$ One cow was culled after first luteal phase but before start of a new estrous cycle.

occurrence of PCL type I and II was compared with only normal progesterone profiles $(\mathrm{n}=335)$.

\section{Statistical Analysis}

Associations Between C-LA and PCL, Milk Yield, Parity, Housing, Year, and Disease Before $\boldsymbol{C}-\boldsymbol{L} \boldsymbol{A}$. Mixed linear models were performed using SPSS (SPSS Inc., 2006) to assess relationships between the natural logarithm of days to C-LA (lnC-LA) and the explanatory variables milk yield at the fourth week of lactation (MY), parity (first, second, > second), year of study (1994 to 1998, 1999 to 2001, and 2005 to 2007), housing (freestall or tiestall), disease treatment before C-LA $(1 / 0)$, PCL type I $(1 / 0)$, and the summated occurrence of PCL type I and II $(1 / 0)$. The outcome variable days to C-LA was transformed by natural logarithm to obtain approximate normality of residuals. Explanatory variables associated with $\operatorname{lnC}$ LA with $P<0.20$ were included in an extended model. Level of concentrate was included in the model as a random effect. Covariance between multiple lactations within the same cow was accounted for by a compound symmetry correlation structure. Multiple comparison adjustment for the pairwise difference in least squares means (LS-means) was performed using the Bonferroni option in SPSS (SPSS Inc., 2006).

Associations Between PCL and MY, Concentrate Allocation, Parity, Year, Housing, Disease Before $\boldsymbol{C}-\boldsymbol{L A}$, and $\mathbf{D O V}$. The associations between the outcome PCL type I (1/0), PCL type II, or the summated occurrence of PCL type I and II, and the explanatory variables were tested separately using a general estimating equation (GEE) approach in SPSS adjusted for multiple lactations within the same cow by the use of a compound symmetry correlation structure (SPSS Inc., 2006). The following variables were used when the likelihood of PCL in separate (univariate) models was evaluated: MY, concentrate allocation $(\leq 6$ $\mathrm{kg}, 7-9 \mathrm{~kg}$, and $\geq 10 \mathrm{~kg}$ ), parity (first, second, >second), year of study (1994 to 1998, 1999 to 2001, and 2005 to 2007), housing (freestall or tiestall), disease treatment before C-LA, and the summated occurrence of DOV type I and II (1/0). An extended model was not constructed because year of trial was the only explanatory variable with $P<0.20$.

Likelihood of Pregnancy to First AI Related to a Previous Episode of $\boldsymbol{P C L}$. The associations between the likelihood of pregnancy to first AI (1/0) and the explanatory variables PCL type I, PCL type II, or the summated occurrence of PCL type I and II were tested separately using the GEE approach in SPSS (SPSS Inc., 2006). The associations were adjusted for multiple lactations within the same cow by the use of a compound symmetry correlation structure. The interval from calving to first AI was originally included in all models but omitted from the analyses because it was not associated with the outcome variable, pregnancy to first AI.

Likelihood of AI During the Luteal Phase Related to a Previous Episode of PCL. The associations between the likelihood of performing the first AI 
during the luteal phase (progesterone concentration $\geq 3$ $\mathrm{ng} / \mathrm{mL} ; 1 / 0)$ and the explanatory variables PCL type I, PCL type II, or the summated occurrence of PCL types I and II were tested separately using the GEE approach in SPSS (SPSS Inc., 2006). The associations were adjusted for multiple lactations within the same cow by the use of a compound symmetry correlation structure. Statistical significance was considered to be $P<0.05$ for all analyses.

\section{RESULTS}

The overall average $\operatorname{lnC}$-LA was $3.261 \pm 0.025$, representing an interval from calving to C-LA of $26.1 \mathrm{~d}$. Average milk yields in the fourth week of lactation were $22.0,27.2$, and $30.1 \mathrm{~kg}$ for first, second, and > second parity, respectively.

\section{Length of Luteal Phases and Interovulatory Intervals}

Lengths of the first 4 luteal phases and interovulatory intervals with PCL and DOV included and excluded are presented in Table 3. Length of first luteal phase was shorter than the lengths of consecutive luteal phases. Length of first interovulatory interval, which is an estimate of estrous cycle length, was shorter in the first cycle compared with subsequent cycles.

\section{Progesterone Profile Abnormalities}

Delayed ovulation type I was present in $14.7 \%$ $(74 / 502)$ of the lactations; $\mathrm{n}=42,22$, and 10 in first, second, and >second parity, respectively. The length of DOV type I was 50 to $130 \mathrm{~d}$, with a mean of $76.0 \pm$ 2.4 d. Delayed ovulation type II was present in $2.8 \%$ $(14 / 502)$ of the lactations; $\mathrm{n}=5,6$, and 3 in first, second, and >second parity, respectively. The length of DOV type II was 12 to $101 \mathrm{~d}$, with a mean of $30.9 \pm 6.8$ d. Five cows experienced both DOV type I and type II during the same lactation.

In total, PCL was present in $9.6 \%(46 / 480)$ of the lactations. Two cows experienced both types of PCL in the same lactation. Persistent corpus luteum type I was present in $6.7 \%(32 / 480)$ of lactations; $\mathrm{n}=13,9$, and 10 for first, second, and > second parity, respectively. The length of PCL type I was 19 to $105 \mathrm{~d}$, with a mean of $33.8 \pm 3.2$ d. Persistent corpus luteum type II was present in $3.3 \%(16 / 480)$ of lactations; $\mathrm{n}=4,4$, and 8 for first, second, and >second parity, respectively. The length of PCL type II was 19 to $42 \mathrm{~d}$, with a mean of $27.5 \pm 2.2 \mathrm{~d}$.

Three cows experienced both DOV type I and PCL type I during the same lactation, and one cow experienced both DOV type I and PCL type II during the same lactation.

\section{Associations Between C-LA and MY, PCL, Parity, Year, Housing, and Disease Before C-LA}

When the variable $\operatorname{lnC}-\mathrm{LA}$ was tested against individual explanatory variables, $P$-values $\leq 0.20$ (type III statistic) were calculated for MY $(P=0.03)$, parity $(P$ $<0.01)$, housing $(P<0.01)$, the summated occurrence of PCL type I and II $(P=0.04)$, PCL type I $(P=$ $0.08)$, and PCL type II $(P=0.18)$.

Associations between $\operatorname{lnC}$-LA and the explanatory variables MY, parity, housing, and PCL (type I or the summated occurrence of PCL type I and II), when entered simultaneously in the extended mixed-model analysis, are presented in Table 4 . In the type III statistics $F$-test, $\operatorname{lnC}$-LA was associated with MY $(P<$ $0.01)$, parity $(P<0.01)$, housing $(P=0.01)$, and PCL type I $(P=0.01)$ or the summated occurrence of PCL type I and II $(P=0.02)$. In the model with PCL type I included as explanatory variable, the LS-means for lnC-LA were $3.141 \pm 0.111$ when PCL type I was present and $3.382 \pm 0.065$ when PCL type I was absent, representing an interval from calving to C-LA of 23.1 and $29.4 \mathrm{~d}$, respectively. The LS-means for $\operatorname{lnC}-\mathrm{LA}$ were $3.468 \pm 0.090,3.179 \pm 0.085$, and $3.137 \pm 0.085$, representing an interval from calving to C-LA of 32.1, 24.0 , and $23.0 \mathrm{~d}$ for first, second, and > second parity, respectively. The LS-means for lnC-LA were $3.194 \pm$ 0.079 (freestall) and $3.329 \pm 0.087$ (tiestall), representing an interval from calving to C-LA of 24.4 and $27.9 \mathrm{~d}$ for freestall and tiestall, respectively.

In the model with the summated occurrence of PCL type I and II included as explanatory variable, the LSmeans for $\operatorname{lnC}$-LA were $3.187 \pm 0.099$ when PCL type I or II was present and $3.384 \pm 0.065$ when PCL type I or II was absent, representing an interval from calving to C-LA of 24.2 and 29.5 d, respectively. The LS-means for $\operatorname{lnC}$-LA were $3.490 \pm 0.087,3.201 \pm 0.080$, and $3.165 \pm 0.080$ for first, second, and >second parity, representing an interval from calving to C-LA of 32.8, 24.6 , and $23.7 \mathrm{~d}$ for first, second, and > second parity, respectively. The LS-means for lnC-LA were $3.216 \pm$ 0.075 (freestall) and $3.355 \pm 0.082$ (tiestall), representing an interval from calving to C-LA of 24.9 and $28.6 \mathrm{~d}$ for freestall and tiestall, respectively.

\section{Associations Between the Likelihood of PCL and: MY, Concentrate Allocation, Parity, Year, Housing, DOV, and Disease Before C-LA}

The separate GEE analyses on the relationships between the summated occurrence of PCL type I and II and the explanatory variables MY, concentrate allocation, parity, year, housing, the occurrence of DOV type I or II, and disease treatment before C-LA are pre- 
Table 4. Associations between number of days to commencement of luteal activity ${ }^{1}$ (natural logarithmic transformed) and the explanatory variables

\begin{tabular}{|c|c|c|c|c|c|c|}
\hline \multirow[b]{2}{*}{ Item } & \multicolumn{3}{|c|}{ PCL type $\mathrm{I}^{2}$} & \multicolumn{3}{|c|}{ PCL type $\mathrm{I}$ and $\mathrm{II}^{2}$} \\
\hline & $\beta$ & $\mathrm{SE}$ & $P$-value & $\beta$ & $\mathrm{SE}$ & $P$-value \\
\hline First parity & - & - & - & - & - & - \\
\hline Second parity & -0.290 & 0.060 & $<0.01$ & -0.289 & 0.060 & $<0.01$ \\
\hline$>$ Second parity & -0.331 & 0.072 & $<0.01$ & -0.325 & 0.072 & $<0.01$ \\
\hline PCL: $\mathrm{no}^{3}$ & - & - & - & - & - & - \\
\hline PCL: yes & -0.241 & 0.093 & 0.01 & -0.198 & 0.079 & 0.01 \\
\hline Tiestall $^{3}$ & - & - & - & - & - & - \\
\hline Freestall & -0.136 & 0.05 & 0.01 & -0.139 & 0.054 & 0.01 \\
\hline MY & 0.029 & 0.005 & $<0.01$ & 0.029 & 0.005 & $<0.01$ \\
\hline Intercept & 2.885 & 0.125 & $<0.01$ & 2.893 & 0.125 & $<0.01$ \\
\hline
\end{tabular}

${ }^{1}$ Associations assessed in 2 separate multivariable mixed linear models corrected for level of concentrate allocation as random effect variable and adjusted for multiple lactations within the same cow by the use of a compound symmetry correlation matrix. Explanatory variables included in the models were parity, milk yield in the fourth week of lactation (MY), housing (freestall, tiestall), and persistent corpus luteum (PCL) type I or the summated occurrence of PCL type I and type II.

${ }^{2} \mathrm{PCL}$ type $\mathrm{I}=$ delayed luteolysis with milk progesterone concentration $\geq 3 \mathrm{ng} / \mathrm{mL}$ for $\geq 19 \mathrm{~d}$ during the first estrous cycle postpartum; PCL type II = delayed luteolysis during estrous cycles after the first cycle postpartum.

${ }^{3}$ Categorical variables assigned as baselines.

sented in Table 5. There were no associations between the summated occurrence of PCL type I and II and the predictors when assessed separately in the GEE analysis.

\section{Likelihood of Pregnancy to First Al Related to a Previous Episode of PCL}

Of 476 lactations presented for AI after calving, 256 $(53.8 \%)$ resulted in pregnancy after first AI. Number of observations and odds ratios for pregnancy to first AI in cows that experienced PCL type I or the summated occurrence of PCL type I and II are presented in Table 6. There were no associations between the likelihood of pregnancy to first AI and a previous episode of PCL type I or the summated occurrence of PCL type I and II compared with cows with normal progesterone profiles.

\section{Likelihood of Al During the Luteal Phase Related to a Previous Episode of PCL}

Overall, 12.4\% (56/450) of the AI were performed during the luteal phase. Pregnancy to first AI was recorded to be $60.7 \%$ (239/394) in the 394 first AI performed when milk progesterone concentrations were known to be low. Associations between first AI during the luteal phase and the occurrence of PCL type I, PCL type II, or the summated occurrence of PCL types I and II are presented in Table 7. The likelihood of performing the first AI during the luteal phase was 6.8 times higher in cows with PCL type II and 3.2 times higher for the summated occurrence of PCL type I and II compared with cows with normal progesterone profiles.

\section{DISCUSSION}

The feeding regimens and overall herd management employed in the current study reflect those commonly employed by Norwegian farmers. Thus, the results presented should give reliable information about luteal function in Norwegian Red cows. However, clinical trials differ from field environments, and this limitation should be taken into account when the findings of the study are interpreted.

The definitions of DOV and PCL and sample frequency in the current study are the same as used by Royal et al. (2000) and Petersson et al. (2007). In the studies conducted by Opsomer et al. (2000) and Shrestha et al. (2004), the definitions of DOV and PCL are slightly different but comparable with the definitions of the current study.

The occurrence of PCL was generally low in Norwegian Red compared with other dairy breeds studied (Opsomer et al., 1998; Royal et al., 2000; Shrestha et al., 2004; Samarütel et al., 2008). Whether this is related to the inclusion of female fertility in the breeding program since 1972 remains unknown (Andersen-Ranberg et al., 2005; Steine et al., 2008). However, population studies of reproductive performance in the breed have shown encouraging results (Garmo et al., 2008). The interval to C-LA and the effect of energy balance, parity, and genetic merit for milk yield and fertility in Norwegian Red cows has been described previously (Garmo et al., 
Table 5. Likelihood of persistent corpus luteum (PCL) ${ }^{1}$ type I and II as assessed by general estimating equations adjusted for multiple lactations within the same cow by the use of a compound symmetry correlation matrix $^{2}$

\begin{tabular}{|c|c|c|c|c|c|}
\hline Item & $\mathrm{n}=\mathrm{PCL} /$ overall & $\beta$ & $\mathrm{SE}$ & OR & $P$-value \\
\hline MY & $43 / 465$ & -0.003 & 0.026 & 0.997 & 0.92 \\
\hline Concentrate & $46 / 464$ & - & - & - & 0.27 \\
\hline$\leq 6 \mathrm{~kg}^{3}$ & 143 & - & - & 1.0 & - \\
\hline$\overline{7}-9 \mathrm{~kg}$ & 185 & -0.106 & 0.383 & 0.899 & - \\
\hline$\geq 10 \mathrm{~kg}$ & 136 & 0.452 & 0.385 & 1.571 & - \\
\hline Parity & $46 / 480$ & - & - & - & 0.63 \\
\hline First $^{3}$ & 167 & - & - & 1.0 & - \\
\hline Second & 164 & -0.188 & 0.363 & 0.829 & - \\
\hline$>$ Second & 149 & 0.184 & 0.360 & 1.203 & - \\
\hline Year & $46 / 480$ & - & - & - & 0.10 \\
\hline 1994-1998 & 223 & - & - & 1.0 & - \\
\hline 1999-2001 & 120 & 0.410 & 0.444 & 1.507 & - \\
\hline $2005-2007$ & 137 & 0.803 & 0.377 & 2.231 & - \\
\hline Housing & $45 / 473$ & - & - & - & 0.60 \\
\hline Tiestall $^{3}$ & 141 & - & - & 1.0 & - \\
\hline Freestall & 332 & 0.194 & 0.370 & 1.214 & - \\
\hline Disease before C-LA & $46 / 480$ & & & & 0.30 \\
\hline $\mathrm{No}^{3}$ & 401 & - & - & 1.0 & - \\
\hline Yes & 79 & 0.381 & 0.369 & 1.463 & - \\
\hline DOV type I and $\mathrm{II}^{4}$ & $46 / 480$ & - & - & - & 0.31 \\
\hline Not present $^{3}$ & 414 & - & - & 1.0 & - \\
\hline Present & 66 & -0.559 & 0.552 & 0.572 & - \\
\hline
\end{tabular}

${ }^{1} \mathrm{PCL}$ type $\mathrm{I}=$ delayed luteolysis with milk progesterone concentration $\geq 3 \mathrm{ng} / \mathrm{mL}$ for $\geq 19 \mathrm{~d}$ during the first estrous cycle postpartum; PCL type II = delayed luteolysis during estrous cycles after the first cycle postpartum.

${ }^{2}$ The associations were assessed in separate models for each of the fixed-effect variables: milk yield in the fourth week of lactation (MY), concentrate allocation $(\leq 6,7-9$, and $\geq 10 \mathrm{~kg}$ ), parity (first, second, and $>$ second), year of study, the sum of delayed ovulation (DOV) type I and II, disease before commencement of luteal activity (C-LA), and housing (freestall, tiestall).

${ }^{3}$ Categorical variables assigned as baselines.

${ }^{4} \mathrm{DOV}$ type $\mathrm{I}=$ prolonged anovulatory period with milk progesterone concentration $<3 \mathrm{ng} / \mathrm{mL}$ for $\geq 50 \mathrm{~d}$ postpartum; DOV type II = prolonged interluteal interval with milk progesterone $<3 \mathrm{ng} / \mathrm{mL}$ for $\geq 12 \mathrm{~d}$ between 2 luteal phases.

2009). Petersson et al. (2006) reported a slightly less frequent occurrence of PCL, compared with the current study, in the Swedish Red and Whites and Swedish Holstein, in which fertility also has been included in the breeding program since the 1970s. Petersson et al. (2006) also reported that Swedish Holstein had a greater risk for atypical progesterone profiles compared with the Swedish Red and Whites.
The interval from calving to C-LA was associated with the occurrence of PCL in the current study. Heritability for early C-LA is reported to be 0.16 to 0.21 (Darwash et al., 1997b; Royal et al., 2002; Petersson et al., 2007), whereas traditional fertility traits such as nonreturn rate, calving interval, interval to first AI, and number of inseminations per conception, which are the basis in breeding for increased fertility, have

Table 6. Likelihood of pregnancy to first AI assessed by general estimating equations adjusted for multiple lactations within the same cow by the use of a compound symmetry correlation matrix ${ }^{1}$

\begin{tabular}{|c|c|c|c|c|c|c|}
\hline Item & $\mathrm{n}$ & $\beta$ & $\mathrm{SE}$ & Odds ratio (OR) & $\begin{array}{l}95 \% \text { Confidence } \\
\text { interval for OR }\end{array}$ & $P$-value \\
\hline \multicolumn{7}{|l|}{ PCL type $\mathrm{I}^{2}$} \\
\hline Present & 20 & -0.725 & 0.467 & 0.484 & $0.194-1.210$ & 0.12 \\
\hline \multicolumn{7}{|l|}{ PCL type $\mathrm{I}$ and $\mathrm{II}^{2}$} \\
\hline Present & 29 & -0.456 & 0.396 & 0.634 & $0.292-1.377$ & 0.25 \\
\hline Normal profiles & 316 & - & - & 1.0 & - & - \\
\hline
\end{tabular}

${ }^{1}$ The analyses were performed in separate analyses for persistent corpus luteum (PCL) type I or the summated occurrence of PCL type I and II. The baseline control group consisted exclusively of lactations in which normal luteal activity had been recorded.

${ }^{2} \mathrm{PCL}$ type I = delayed luteolysis with milk progesterone concentration $\geq 3 \mathrm{ng} / \mathrm{mL}$ for $\geq 19 \mathrm{~d}$ during the first estrous cycle postpartum; PCL type $\mathrm{II}=$ delayed luteolysis during estrous cycles after the first cycle postpartum. 
Table 7. Likelihood of performing first AI during the luteal phase (progesterone $\geq 3 \mathrm{ng} / \mathrm{mL}$ ) assessed by general estimating equation adjusted for multiple lactations within the same cow by the use of a compound symmetry correlation matrix ${ }^{1}$

\begin{tabular}{|c|c|c|c|c|c|c|}
\hline Item & $\mathrm{n}$ & $\beta$ & $\mathrm{SE}$ & $\begin{array}{l}\text { Odds ratio } \\
\text { (OR) }\end{array}$ & $\begin{array}{l}95 \% \text { Confidence } \\
\text { interval for OR }\end{array}$ & $P$-value \\
\hline \multicolumn{7}{|l|}{ PCL type $\mathrm{I}^{2}$} \\
\hline \multicolumn{7}{|l|}{ PCL type $\mathrm{II}^{2}$} \\
\hline Present & 11 & 1.921 & 0.627 & 6.826 & $1.996-23.349$ & $<0.01$ \\
\hline Normal profiles & 335 & - & - & 1.0 & - & - \\
\hline Normal profiles & 335 & - & - & 1.0 & - & - \\
\hline
\end{tabular}

${ }^{1}$ The analyses were performed in separate analyses for persistent corpus luteum (PCL) type I, PCL type II, or the summated occurrence of PCL type I and II. The baseline control group consisted exclusively of lactations in which normal luteal activity had been recorded.

${ }^{2} \mathrm{PCL}$ type $\mathrm{I}=$ delayed luteolysis with milk progesterone concentration $\geq 3 \mathrm{ng} / \mathrm{mL}$ for $\geq 19 \mathrm{~d}$ during the first estrous cycle postpartum; PCL type $\mathrm{II}=$ delayed luteolysis during estrous cycles after the first cycle postpartum.

heritabilities from 0.018 to 0.040 (Pryce et al., 1997; Wall et al., 2003; Jamrozik et al., 2005). Selection for shorter intervals to C-LA, which has a moderate heritability, may be a feasible approach to improving fertility (Darwash et al., 1997b). However, inclusion of C-LA only as a fertility trait in a breeding program should be considered with caution because of the increased risk of PCL rather than continuous cyclical luteal activity after early C-LA (Opsomer et al., 2000; Royal et al., 2002; Petersson et al., 2007). In the current study, the interval to C-LA was approximately $5 \mathrm{~d}$ shorter in cows that subsequently experienced PCL, which demonstrates the importance of elucidating the potential negative side effects of breeding for early C-LA.

A previous episode of PCL was not associated with the likelihood of pregnancy to first insemination in cows that were inseminated while having low progesterone levels. The latter is in contrast with both Royal et al. (2000), who reported PCL to be associated with a decrease in pregnancy to first AI, and Shrestha et al. (2004), who reported a lower pregnancy rate within 100 DIM. However, cows experiencing PCL were more likely to be inseminated during the luteal phase, which might explain the results obtained in previous studies of associations between pregnancy rate and PCL by Royal et al. (2000) and Shrestha et al. (2004). To our knowledge, the relationship between the increased likelihood of insemination during the luteal phase and the occurrence of PCL has not been reported before. The occurrence of PCL type II was highly significantly associated, whereas PCL type I showed a tendency to be associated with the likelihood of AI during the luteal phase. Cows that experienced PCL type II could have expressed signs of estrus during a previous cycle and, hence, presented for insemination at the expected time for the following estrus. Another reason could be altered behavior in these animals because of ovarian pathology (Vanholder et al., 2006). First AI was performed during the luteal phase in $12.4 \%$ of the lactations, which is greater than the population estimate of 4.4\% (Andresen and Onstad, 1979) and 4.9\% (Garmo et al., 2008) in Norwegian Red cows.

There were no associations between the occurrence of PCL and milk yield, concentrate allocation, parity, year of trial, disease before C-LA, or DOV. Windig et al. (2008) could not find an association between prolonged luteal activity and milk production. Pollott and Coffey (2008) reported a greater-than-expected number of PCL type II in cows fed high levels of concentrate, and genetic line did not affect the occurrence of PCL type I or type II. Parity was not associated with the occurrence of PCL in the current study, which contrasts with Opsomer et al. (2000), who reported parity to be a risk factor for prolonged luteal phases. Opsomer et al. (2000) reported that the most important risks for delayed luteolysis were early C-LA, occurrence of metritis, retained placenta, calving problems, and abnormal vaginal discharge. Petersson et al. (2006) also reported endometritis to be a risk factor for PCL. Thus, prolonged luteal phases could be the result of uterine problems rather than ovarian pathology. It has been suggested that ovulation before complete uterine involution might increase the risk of developing pyometra (Opsomer et al., 2000). In the current study, the low occurrence of PCL could partly be explained by the very low number of puerperal problems in the cows included. This corresponds well with the population of Norwegian Red cows in which the incidence rates per 100 cow-years in 2005 were 1.2, 3.1, 0.2, and 0.9 for dystocia; retained placenta; abortion; and metritis, vaginitis or salphangitis, respectively (Østerås et al., 2007).

Delayed ovulation type I was present in $14.7 \%$ of the profiles, which was less than in some previous studies 
of Holstein cows in which DOV type I was reported to be $25.3 \%$ (Samarütel et al., 2008) and 20.5\% (Opsomer et al., 1998), whereas an estimate of $15.6 \%$ was found in Swedish Holstein and Swedish Red and Whites (Petersson et al., 2006). However, Shrestha et al. (2004) reported the proportion of DOV type I to be $13.2 \%$, whereas Royal et al. (2000) reported 10.9 and $12.9 \%$ from 1975 to 1982 and from 1995 to 1998, respectively. In the current study, DOV type II occurred in only $2.8 \%$ of the profiles. The incidence agrees with previous studies in Holstein cows that reported the proportion of DOV type II to be 4.2 (Samarütel et al., 2008), 3.3 (Shrestha et al., 2004), and 3.0\% (Opsomer et al., 1998) but is less than the DOV type II estimates of 12.9 and $6.6 \%$ reported by Royal et al. (2000) and Petersson et al. (2006), respectively.

Length of first luteal phases $(10.5 \mathrm{~d})$ agreed with Royal et al. (2000), who reported the length of first luteal phase to be $10.8 \mathrm{~d}$ in British Friesian from 1975 to 1982. The same study reported the length of first luteal phase to be $14.6 \mathrm{~d}$ from 1995 to 1998 after there had been a large breed substitution of British Friesian with North American Holstein and a significant increase in milk yield in the population.

Length of first interovulatory interval, a measure of the estrous cycle length, was 17.4 and $19.3 \mathrm{~d}$ when profiles with abnormalities were excluded and included, respectively. First interovulatory interval was shorter in the first cycle compared with consecutive cycles (20.6 to 20.7 d) in cows with normal profiles. Royal et al. (2000) reported increased length of first interovulatory interval from $18.9 \mathrm{~d}$ (1975 to 1982) to $22.5 \mathrm{~d}$ (1995 to 1998) when both normal and abnormal profiles were included. Fonseca et al. (1983) reported the length of the first estrous cycle to be $17.1 \mathrm{~d}$ and the length of the second estrous cycle to be $21.4 \mathrm{~d}$ in Holstein cows in North Carolina when only normal cows were included. Thus, the current length of the estrous cycles, with or without abnormalities, in Norwegian Red cows corresponds well with estrous cycle length observed in the Holstein breed 25 years ago. For future estimates of estrous cycle length, it is feasible to investigate cycle length with profile abnormalities included and excluded. This would provide a more reliable assessment of whether the increased cycle length is due to PCL and DOV type II or other causes.

\section{CONCLUSIONS}

The occurrence of DOV and PCL in Norwegian Red cows in the current study is less frequent than that reported in most other dairy populations. Cows experiencing PCL had shorter interval to C-LA. The occurrence of PCL did not affect pregnancy to first AI when
AI was performed at low progesterone concentrations, but cows with PCL were more likely to experience AI during a luteal phase.

\section{ACKNOWLEDGMENTS}

The authors gratefully acknowledge the staff at the Norwegian University of Life Sciences, Animal Production Experimental Center, Ås, for taking good care of the animals and for skillful registration of data. We also acknowledge the staff at the Norwegian University of Life Sciences, Department of Animal and Aquacultural Sciences, Ås, and the Norwegian School of Veterinary Science, Department of Production Animal Clinical Sciences, Oslo, for technical assistance. Support for the preparation of the antiprogesterone monoclonal antibody and the progesterone peroxidase conjugate was provided by the Estonian Science Foundation (Tallinn). These experiments were financially supported by Research Council (Oslo) of Norway, TINE Norwegian Dairies (Ås), and GENO Breeding and AI Association (Hamar, Norway).

\section{REFERENCES}

Andersen-Ranberg, I. M., G. Klemetsdal, B. Heringstad, and T. Steine. 2005. Heritabilities, genetic correlations, and genetic change for female fertility and protein yield in Norwegian dairy cattle. J. Dairy Sci. 88:348-355.

Andresen, Ø., and O. Onstad. 1979. Brunstkontroll og drektighetskontroll hos ku ved hjelp av progesteronbestemmelse i melk (Estrus detection and pregnancy testing in the cow using the milk progesterone test). Nor. Vet. Tidsskr. 91:411-421.

Darwash, A. O., G. E. Lamming, and J. A. Woolliams. 1997a. The phenotypic association between the interval to past-partum ovulation and traditional measures of fertility in dairy cattle. Anim. Sci. 65:9-16.

Darwash, A. O., G. E. Lamming, and J. A. Woolliams. 1997b. Estimation of genetic variation in the interval from calving to postpartum ovulation of dairy cows. J. Dairy Sci. 80:1227-1234.

Edmonson, A. J., I. J. Lean, L. D. Weaver, T. Farver, and G. Webster. 1989. A body condition scoring chart for Holstein dairy cows. J. Dairy Sci. 72:68-78.

Fonseca, F. A., J. H. Britt, B. T. McDaniel, J. C. Wilk, and A. H. Rakes. 1983. Reproductive traits of Holsteins and Jerseys: Effects of age, milk yield, and clinical abnormalities on involution of cervix and uterus, ovulation, estrous cycles, detection of estrus, conception rate, and days open. J. Dairy Sci. 66:1128-1147.

Garmo, R. T., A. O. Refsdal, K. Karlberg, E. Ropstad, A. Waldmann, J. F. Beckers, and O. Reksen. 2008. Pregnancy incidence in Norwegian Red cows using nonreturn to estrus, rectal palpation, pregnancy-associated glycoproteins, and progesterone. J. Dairy Sci. 91:3025-3033.

Garmo, R. T., E. Ropstad, Ø. Havrevoll, E. Thuen, H. Steinshamn, A. Waldmann, and O. Reksen. 2009. Commencement of luteal activity in three different selection lines for milk yield and fertility in Norwegian Red cows. J. Dairy Sci. 92:2159-2165.

Jamrozik, J., J. Fatehi, G. J. Kistemaker, and L. R. Schaeffer. 2005. Estimates of genetic parameters for Canadian Holstein female reproduction traits. J. Dairy Sci. 88:2199-2208.

Lucy, M. C. 2001. Reproductive loss in high-producing dairy cattle: Where will it end? J. Dairy Sci. 84:1277-1293.

Opsomer, G., M. Coryn, H. Deluyker, and A. de Kruif. 1998. An analysis of ovarian dysfunction in high yielding dairy cows after 
calving based on progesterone profiles. Reprod. Domest. Anim. 33:193-204.

Opsomer, G., Y. T. Grohn, J. Hertl, M. Coryn, H. Deluyker, and A. de Kruif. 2000. Risk factors for post partum ovarian dysfunction in high producing dairy cows in Belgium: A field study. Theriogenology 53:841-857.

Østerås, O., H. Solbu, A. O. Refsdal, T. Roalkvam, O. Filseth, and A. Minsaas. 2007. Results and evaluation of thirty years of health recordings in the Norwegian dairy cattle population. J. Dairy Sci. 90:4483-4497.

Petersson, K. J., B. Berglund, E. Strandberg, H. Gustafsson, A. P. F. Flint, J. A. Woolliams, and M. D. Royal. 2007. Genetic analysis of postpartum measures of luteal activity in dairy cows. J. Dairy Sci. 90:427-434.

Petersson, K. J., H. Gustafsson, E. Strandberg, and B. Berglund. 2006. Atypical progesterone profiles and fertility in Swedish dairy cows. J. Dairy Sci. 89:2529-2538.

Pollott, G. E., and M. P. Coffey. 2008. The effect of genetic merit and production system on dairy cow fertility, measured using progesterone profiles and on-farm recording. J. Dairy Sci 91:3649-3660.

Pryce, J. E., M. D. Royal, P. C. Garnsworthy, and I. L. Mao. 2004. Fertility in the high-producing dairy cow. Livest. Prod. Sci. 86:125-135.

Pryce, J. E., R. F. Veerkamp, R. Thompson, W. G. Hill, and G. Simm. 1997. Genetic aspects of common health disorders and measures of fertility in Holstein Friesian dairy cattle. Anim. Sci. 65:353-360.

Royal, M. D., A. O. Darwash, A. P. F. Flint, R. Webb, J. A. Woolliams, and G. E. Lamming. 2000. Declining fertility in dairy cattle: Changes in traditional and endocrine parameters of fertility. Anim. Sci. 70:487-501.

Royal, M. D., A. P. F. Flint, and J. A. Woolliams. 2002. Genetic and phenotypic relationships among endocrine and traditional fertility traits and production traits in Holstein-Friesian dairy cows. J. Dairy Sci. 85:958-967.
Samarütel, J., K. Ling, A. Waldmann, H. Jaakson, T. Kaart, and A. Leesmäe. 2008. Field trial on progesterone cycles, metabolic profiles, body condition score and their relation to fertility in Estonian Holstein dairy cows. Reprod. Domest. Anim. 43:457463.

Shrestha, H. K., T. Nakao, T. Suzuki, T. Higaki, and M. Akita. 2004. Effects of abnormal ovarian cycles during pre-service period postpartum on subsequent reproductive performance of highproducing Holstein cows. Theriogenology 61:1559-1571.

SPSS Inc. 2006. SPSS Advanced Models15.0. SPSS Inc., Chicago, IL.

Steine, G.. D. Kristofersson, and A. G. Guttormsen. 2008. Economic evaluation of the breeding goal for Norwegian Red dairy cattle. J. Dairy Sci. 91:418-426.

Vanholder, T., G. Opsomer, and A. de Kruif. 2006. Aetiology and pathogenesis of the cystic ovarian follicles in dairy cattle: A review. Reprod. Nutr. Dev. 46:105-119.

Veerkamp, R. F., E. P. C. Koenen, and G. De Jong. 2001. Genetic correlations among body condition score, yield, and fertility in first-parity cows estimated by random regression models. J. Dairy Sci. 84:2327-2335.

Waldmann, A. 1993. Enzyme immunoassay (EIA) for milk progesterone using a monoclonal antibody. Anim. Reprod. Sci. 34:19-30.

Waldmann, A. 1999. Monoclonal antibodies to progesterone: Characterization and selection for enzyme immunoassay in bovine milk. Hybridoma 18:289-296.

Wall, E., S. Brotherstone, J. A. Woolliams, G. Banos, and M. P. Coffey. 2003. Genetic evaluation of fertility using direct and correlated traits. J. Dairy Sci. 86:4093-4102.

Windig, J. J., B. Beerda, and R. F. Veerkamp. 2008. Relationship between milk progesterone profiles and genetic merit for milk production, milking frequency, and feeding regimen in dairy cattle. J. Dairy Sci. 91:2874-2884. 